Int. J. Electrochem. Sci., 13 (2018) 1084 - 1095

\title{
Cu-Ni Alloy Catalyzed Electrochemical Carboxylation of Benzyl Bromide with Carbon Dioxide in Ionic Liquid 1-Butyl-3- methylimidazolium tetrafluoroborate
}

\author{
Dai Yimin ${ }^{1, *}$, Niu Lanli ${ }^{1}$, Liu Hui $^{1}$, Zou Jiaqi ${ }^{1}$, Yu Linping ${ }^{1}$, Feng Qiuju ${ }^{2}$ \\ ${ }^{1}$ School of Chemistry and Biological Engineering, Hunan Provincial Key Laboratory of Materials \\ Protection for Electric Power and Transportation, Changsha University of Science and Technology, \\ Changsha 410114, China \\ ${ }^{2}$ College of Chemistry and Chemical Engineering, Jishou University, Jishou 416000, China \\ E-mail: yimindai@ sohu.com
}

doi: $10.20964 / 2018.01 .85$

Received: 28 July 2017 / Accepted: 9 October 2017 / Published: 16 December 2017

\begin{abstract}
A novel, direct and efficient electroreduction method of benzyl bromide in ionic liquid $\mathrm{BMIMBF}_{4}$ has been developed by potentiostatic electrolysis. Under the atmospheric pressure of $\mathrm{CO}_{2}$, the electrosynthesis was performed in an undivided cell with $\mathrm{Cu}-\mathrm{Ni}$ cathode and $\mathrm{Al}$ anode. A moderate yield (39.4\%) of ethyl phenylacetate $\mathbf{1}$ as the principal product was obtained, accompanied astonishingly by yield $(4.6 \%)$ of benzyl ether 2 . Synthetic factors such as electrode material, working potential and electric charge were found to influence the carboxylation yields. The results indicate that the porous structure $\mathrm{Cu}-\mathrm{Ni}$ alloy electrode with different adsorption energies for $\mathrm{CO}_{2}$ and benzyl bromide played an ensemble effect role in the reaction efficiency and products distribution. Moreover, the ionic liquid was successfully recycled and a plausible reaction mechanism was proposed.
\end{abstract}

Keywords: Benzyl bromide; Carbon dioxide; Ionic liquid; Electrocarboxylation; $\mathrm{Cu}-\mathrm{Ni}$ alloy

\section{FULL TEXT}

(C) 2018 The Authors. Published by ESG (www.electrochemsci.org). This article is an open access article distributed under the terms and conditions of the Creative Commons Attribution license (http://creativecommons.org/licenses/by/4.0/). 